\title{
Additional physiological races of coffee leaf rust (Hemileia vastatrix) identified in Kenya
}

\author{
Elijah K. Gichuru1, John M. Ithiru1, Maria C. Silva², Ana P. Pereira ${ }^{2}$ \& Vitor M.P. Varzea ${ }^{2}$ \\ ${ }^{1}$ Coffee Research Foundation, P.O.Box 4-00232, Ruiru, Kenya; ${ }^{2}$ Centro de Investigação das Ferrugens do Cafeeiro/ Instituto \\ de Investigação Científica Tropical (CIFC/IICT), Quinta do Marquês, 2784-505, Oeiras, Portugal
}

Author for correspondence: Elijah K. Gichuru, e-mail: ekgichuru@yahoo.com or gichuru.elijah@crf.co.ke

\begin{abstract}
Coffee leaf rust (CLR), caused by the fungus Hemileia vastatrix, is among the most important diseases affecting coffee all over the world. In Kenya, it is currently the second most important disease, and breeding coffee to obtain new resistant cultivars has been a priority. Over time, new rust pathogenic races able to infect hitherto resistant coffee genotypes have been registered. To date, 49 races of the pathogen have been characterized all over the world. The most recent races to be characterized are able to infect derivatives of Timor Hybrid (HDT), which is a major source of resistance in breeding programs. This work aimed to identify new races of the pathogen in Kenya, emphasizing infected leaves sampled from CLR resistant varieties and breeding lines collected from two sites (Ruiru and Koru). Twenty-four samples were characterized, out of which 22 samples corresponded to new races of the pathogen. A total of six new races (III, XVII, XXIII, XXXVI, XLI and XLII) were characterized, revealing three new virulence genes $\left(v_{1}, v_{7}, v_{8}\right)$ and possibly a fourth virulence gene, the $v_{9}$. This finding represents a serious threat to coffee production and also a challenge to coffee breeding programs that are in progress in Kenya.
\end{abstract}

Key words: Coffe, leaf rust, races, resistance, virulence genes.

Coffee has been cultivated in Kenya since around 1900 , brought to the country in small quantities by missionaries. Since then, coffee cultivation has expanded into many areas between 1200 and 2100 meters above sea level and is one of the major mainstays of the country's economy. Occurrence of diseases is one of the main constraints on coffee production. Coffee Leaf Rust (CLR), caused by the fungus Hemileia vastatrix Berk and Br., is currently the second most important disease in Kenya after Coffee Berry Disease (CBD), which is caused by Colletotrichum kahawae Waller and Bridge. CLR was first reported in Kenya in 1913 (Rayner, 1960), but there are records that it was previously noticed in 1861 in Western Kenya near Lake Victoria on uncultivated coffee (Wellman, 1953; Ferreira \& Boley, 1991) implying that this disease may have existed earlier in Eastern Africa. These reports indicate the possibility of a long history of interaction between $H$. vastatrix and Coffea species in the region even before the introduction of Arabica coffee. Over time, many biotic and abiotic factors have changed, affecting the levels of CLR epidemics and durability of coffee resistance to CLR. Among the biotic factors is the selection pressure exerted by coffee cultivars that are introduced, bred and released for cultivation.

The early method used to control CLR was fungicide application (Dowson, 1921). Even at present, a large part of the research effort in Kenya is directed towards the control of the disease by fungicide spraying, because most of the cultivated coffee comprises susceptible cultivars. However, breeding for coffee resistance to $H$. vastatrix physiologic races has gained priority and is expected to be an economical and environmentally friendly control method. A C. arabica cultivar Blue Mountain was first introduced into Kenya in 1913 and it carries the CLR resistance gene $S_{H} 5$. Later, in 1936, another cultivar K7 (with resistance genes $S_{H} 2$ and $S_{H} 5$ ) was selected for its resistance against CLR (Wallis, 1958).

Accessions and derivatives of the inter-specific hybrid Timor Hybrid (HDT) have for a long time been supplied freely by Coffee Rusts Research Centre (CIFC), in Portugal, for breeding against coffee diseases. HDTs are natural hybrids between $C$. arabica and $C$. canephora Pierre and received from the latter the major genes responsible for rust resistance $\left(S_{H} 6, S_{H} 7, S_{H} 8, S_{H} 9\right.$ and others not yet identified) (Rodrigues Jr et al., 1975; Bettencourt \& Rodrigues Jr., 1988; Várzea \& Marques, 2005; Diniz et al., 2012). The use of these major genes in combination can differ when considering different breeding programs and races of $H$. Vastatrix, which arise with virulence genes that can infect the cultivars thus developed.

In Kenya, a breeding program undertaken by the Coffee Research Foundation (CRF) at Ruiru, with a total of 35 progenitors, sought to accumulate both the resistance existing in pure Arabica varieties and that of Robusta origin (derived via the Timor Hybrid) (van der Vossen \& Walyaro, 
1981). The program resulted in the release of the cultivar Ruiru 11 in 1985, which is resistant to CLR and CBD. The cultivar has been planted in all coffee growing areas of the country. Later, further selection among the breeding lines of the program led to the release of the cultivar Batian in the year 2010, which also combines resistance to both CBD and CLR (Gichimu et al., 2010). All of these resistant cultivars are expected to exert selection pressure on the pathogen. Information on the status of the pathogen races in the country has therefore been of concern in breeding of coffee cultivars resistant to CLR (Gichuru, 2005).

Previously, only six races of the pathogen (races I, II, VII, XV, XX, and XXIV) have been identified in Kenya (Thitai \& Okioga, 1977). Races I and II are very common and account for more than $90 \%$ of the leaf rust samples which have been sent from Kenya to the CIFC (Portugal) for race-typing. Races VII, XV and XX are of rare occurrence. However, it must be noted that the rust samples collected for race-typing came from commercial farms planted with susceptible coffee cultivars. On the other hand, the breeding and germplasm conservation fields (museum plots) consist of small portions of genotypes neighboring each other. Furthermore, the individual plants in a breeding plot may comprise unique genotypes due to gene assortment and recombination. Development and maintenance of races of leaf rust is due to exposure of the pathogen to coffee plants with various resistance genes (Varzea \& Marques, 2005). It can therefore be expected that new races of the pathogen are likely to arise in farms with coffee plants with resistance genes and the greater the assortment of the genes, the more the races that may develop. Fields with such characteristics can therefore be considered as 'high risk fields' as far as development of leaf rust races are concerned. Previous efforts to obtain spores from individual plants hitherto known to be resistant to CLR were not successful possibly because infections on those plants had been observed as small lesions with limited sporulation (Gichuru, 2005) and may therefore require some bulking collection strategy. In this study, the above aspects were considered and therefore samples were collected by intensive scouting for CLR infection on coffee cultivars, whose previous records showed tolerance/resistance in commercial and germplasm conservation plots. Further scouting was done on breeding genotypes designed to introduce resistance genes into commercial coffee cultivars. This paper reports the results obtained from the rust samples collected and discusses the significance of the findings.

The Coffee Research Foundation (CRF) in Kenya has coffee conservation field museums both at its main station in Ruiru (latitude $1^{\circ} 06^{\prime} \mathrm{S}$, longitude $36^{\circ} 45^{\prime} \mathrm{E}$ and altitude of 1620 meters above sea level) and five substations in different parts of the country. Earlier disease records have identified resistant and susceptible coffee plants; these were keenly observed for CLR infections, and samples of infected leaves were collected. Different breeding programs for disease resistance maintain plants of different filial generations and these were also scrutinized for infections. The number of infected plants was assessed against the expected number of susceptible plants missing the resistance gene(s) by normal segregation. If the number was higher than would be expected, samples were collected from the infected plants of that population. Field sampling was done in 2009 and 2010. The infected leaves were dried for one week at room temperature while pressed between newspapers. The dried leaves were then sent to CIFC for race identification. Samples from the same coffee cultivar or breeding population and in the same location were combined together to make bulk samples. A total of 24 samples were selected from the 40 field samples sent to CIFC and used for this study (Table 1) excluding samples from traditional fully susceptible cultivars such as 'SL28'. All samples except number 23 were from the Coffee Research Station in Ruiru, while sample 23 was from K7 cultivar in a coffee plantation at CRF Koru, substation in Western Kenya (00 $07^{\prime} \mathrm{S}, 35^{\circ} 16^{\prime} \mathrm{E}$ and an elevation of $\left.1700 \mathrm{M}\right)$. The substation has different coffee cultivars planted in blocks. The methods used for race identification at CIFC have been reported by d'Oliveira and Rodrigues Jr. (1960).

Among the 24 samples tested, 22 samples yielded new races of the pathogen and the remaining two (samples 19 and 22) were identified as race I (Table 1), which is one of the most common in Kenya. In total, six new races were detected: races III, XVII, XXIII and XLII were detected once each, while races XXXVI and XLI were observed six and twelve times, respectively. Apart from recombination of the virulence genes detected in Kenya earlier, three to four new virulence genes were detected: namely, $v_{1}, v_{7}, v_{8}$ and possibly $v_{9}$ (Table 2 ). The virulence gene $v_{6}$ was not detected in the characterized samples.

Knowledge of the races of a pathogen such as CLR is very important in breeding programs and this has been a major research objective. In Kenya, surveys for characterization of races of CLR have in the past concentrated on commercial Coffea arabica farms. Much of the land on these farms is planted with the highly susceptible cultivars SL28 and SL34 but small numbers of 'K7', a tolerant cultivar (with resistance genes $S_{H} 2, S_{H} 5$ ) and very small portions of 'Blue Mountain' (with resistance gene $S_{H} 5$ ) can also be found. The CLR-resistant hybrid Ruiru II was released in 1985 but to date it covers just about $20 \%$ of the land under coffee cultivation. A new CLR resistant cultivar, Batian, was released in the year 2010 and it will take time to significantly replace the traditional varieties. It is recognized that most of the recently discovered CLR races involve the development of virulence genes $v 6-v 9$ that break down the resistance genes $S_{H} 6-S_{H} 9$ present in HDT derivatives (Varzea \& Marques, 2005, Silva et al., 2006, Diniz et al., 2012). It was therefore prudent in this study to focus sampling on "high risk fields". These are breeding and museum plots which expose the pathogen to different assortments of resistance genes. The results support this type of sampling strategy, because 22 out of 24 samples (91.67\%) revealed CLR races 
TABLE 1 - Coffee accessions from which rust samples were obtained and races characterized

\begin{tabular}{|c|c|c|c|c|}
\hline Accession & Germplasm & CLR Phenotype & Virulence genes & Race \\
\hline 1. Pretoria & Museum accession & Tolerant & $2,4,5,8$ & XXXVI \\
\hline 2. Bourbon & Museum accession & Tolerant & $2,5,8$ & XLI \\
\hline 3. Pretoria $x$ SL 28 & Breeding line & Tolerant $\mathrm{x}$ susceptible & $2,4,5,8$ & XXXVI \\
\hline 4. Rume Sudan x SL 28 & Breeding line & Resistant $\mathrm{x}$ susceptible & $2,4,5,8$ & XXXVI \\
\hline 5. HDT x SL 28 & Breeding plot (HDT derivative) & Resistant $\mathrm{x}$ susceptible & $2,5,8$ & XLI \\
\hline 6 CIFC 110/2 & Museum accession & & $2,5,7,8$ or $, 5,7,8,9$ & XLII \\
\hline 7. CR-27 & Breeding line (HDT derivative) & Resistant $\mathrm{x}$ susceptible & $2,4,5,8$ & XXXVI \\
\hline 8. Ennareta & Museum accession & Tolerant & $2,5,8$ & XLI \\
\hline 9. K7 x SL 28 & Breeding line & Tolerant $\mathrm{x}$ susceptible & $2,5,8$ & XLI \\
\hline 10. Rume Sudan & Museum accession & Resistant & $2,5,8$ & XLI \\
\hline 11. Geisha 9 & Museum accession & Tolerant & 1,5 & III \\
\hline 12. Purpurascens & Museum accession & Tolerant & $2,5,8$ & XLI \\
\hline 13. Geisha 10 & Museum accession & Tolerant & $2,4,5,8$ & XXXVI \\
\hline 14. Marsabit & Museum accession & Tolerant & $2,4,5,8$ & XXXVI \\
\hline 15. Mokka 1 & Museum accession & Tolerant & $2,5,8$ & XLI \\
\hline 16. Mundo Novo & Museum accession & Tolerant & $1,2,5$ & XVII \\
\hline 17. S.333 & Museum accession & Tolerant & $2,5,8$ & XLI \\
\hline 18. B.A. 36 & Museum accession & Tolerant & $1,2,4,5$ & XXIII \\
\hline 19. Blue Mountain & Museum accession & Tolerant & 2,5 & I \\
\hline 20. Laurina & Museum accession & Tolerant & $2,5,8$ & XLI \\
\hline 21. Rume Sudan x SL 28 & Breeding line & Resistant $\mathrm{x}$ susceptible & $2,5,8$ & XLI \\
\hline 22. HDT x SL 28 & Breeding line (HDT derivative) & Resistant $\mathrm{x}$ susceptible & 2,5 & I \\
\hline 23. K7 & Commercial variety from Koru & Tolerant & $2,5,8$ & XLI \\
\hline 24. Catimor x SL 28 & Breeding line (HDT derivative) & Resistant $\mathrm{x}$ susceptible & $2,5,8$ & XLI \\
\hline
\end{tabular}

TABLE 2 - Comparison of virulence genes that exist on both the old and new races of $H$. vastatrix in Kenya

\begin{tabular}{llc}
\hline \hline Old Races in Kenya & \multicolumn{1}{c}{ New races detected } & $\begin{array}{c}\text { Additional gene(s) detected } \\
\text { (not in any of the old races) }\end{array}$ \\
\hline I (v2,5) & III (v1,5) & $\mathrm{v} 1$ \\
II (v5) & XVII (v1,2,5) & $\mathrm{v} 1$ \\
VII (v3,5) & XXIII (v1,2,4,5) & $\mathrm{v} 1$ \\
XV (v4,5) & XXXVI (v2,4,5,8) & $\mathrm{v} 8$ \\
XX (v?) & XLI (v2,5,8) & $\mathrm{v} 8$ \\
XXIV (v2,4,5) & XLII (v2,5,7,8 or v 2,5,7,8,9) & $\mathrm{v} 7,8,9$ \\
\hline
\end{tabular}

that had not been detected before in Kenya. The fact that the known races have increased from 6 to 12 (100\% increase) also demonstrates the efficiency of the methodology, but this should be expected, since the last report of a new CLR race in Kenya was based on samples collected in 1976 (Thitai \& Okioga, 1977). It is important to note that currently about 49 races of $H$. vastatrix have been characterized at CIFC, 20 of which are from HDT derivatives. It is therefore possible to recover even more races of the pathogen in future.

A further concern is how the results relate to the real threat to coffee production by comparing the commercial fields to breeding and museum plots. Coffee breeding and germplasm conservation fields comprise plots with different genotypes. In addition, within a breeding population, the individual plants are potentially of unique genetic assortments. This means that a new race that develops on a specific genotype can spread to other plants if they are less resistant in terms of gene to gene matching. This can explain the characterization from non-HDT derivatives, of races with virulence genes matching resistance genes from HDT derivatives (Table 1). The commercial plot of ' $\mathrm{K} 7$ ' in Koru is within $1 \mathrm{~km}$ of blocks with 'Catimors' and 'Ruiru 11', all of which are HDT derivatives. These genotypes could be the source of the $v 8$ gene detected on ' $\mathrm{K} 7$ '. This could also be the case with genes derived from HDT, which were detected in non-HDT derived germplasm either in breeding plots or museums at Ruiru. This situation reflects what is happening on commercial farms in both smallholder and large estates. The new disease-resistant coffee cultivars are being introduced adjacent to fields with susceptible cultivars or planted to replace dead coffee trees. In effect, spores from one genotype are within reach of several other genotypes. 
With the characterization of the new races, it is evident that seven out the nine known $H$. vastatrix genes for virulence do exist in Kenya, especially if the genes in race XLII are confirmed to be $v 2, v 5, v 7, v 8, v 9$ (Table 2). The genes $v 6, v 7, v 8$ and $v 9$ are virulent to HDT derivatives that are the backbone in many breeding programs worldwide. The fact that $v 6$ was not detected in this study does not rule out its existence in the country. The virulence gene $v 3$ was not detected and it matches the resistance gene $S_{H} 3$ derived from $C$. liberica. This species of coffee is represented by a few trees in the museum plots and no rust infection was observed on them. Overall, the results depict a serious threat to breeding programs in the country, and inter-specific breeding with other diploids needs to be incorporated. Noting that many countries use similar breeding genotypes against CLR, it is useful to share information and especially through international collaboration, as also observed by Varzea \& Marques (2005).

\section{ACKNOWLEDGEMENTS}

The authors are grateful to the Coffee Research Foundation, Kenya, and $\mathrm{CFC} / \mathrm{ICO} / 40$ project (Increasing the Resilience of Coffee Production to Leaf Rust and Other Diseases in India and Four African Countries) for financial assistance to the study. The technical assistance of staff at CRF (Plant Pathology and Plant Breeding Departments) and CIFC is also acknowledged. This paper is published with the permission of the Director of Research, CRF.

\section{REFERENCES}

Bettencourt AJ, Rodrigues CJ (1988) Principles and practice of coffee breeding for resistance to rust and other diseases. In: Clarke RJ, Macrae R (Eds.) Coffee Agronomy, v. 4. London UK. Elsevier. pp.199-234.

D’Oliveira B, Rodrigues CJ (1960) 1. A survey of coffee rusts. Oeiras Portugal. Centro de Investigações das Ferrugens do Cafeeiro, Junta de Investigações do Ultramar.
Diniz I, Talhinhas P, Azinheira HG, Várzea V, Medeira C, Maia I, Petitot AS, Nicole M, Fernandez D, Silva MC (2012) Cellular and molecular analyses of coffee resistance to Hemileia vastatrix and non-host resistance to Uromyces vignae in the resistancedonor genotype HDT832/2. European Journal of Plant Pathology 133:141-157

Dowson WJ (1921) Some problem of economic biology in East Africa (Kenya Colony). Annals of Applied Biology 8:83.

Ferreira SA, Boley RA(1991) Hemileia vastatrix. Crop Knowledge Master. Available at: www.extento.hawaii.edu/kbase/crop/type/h vasta.htm. Acessed on 07/27/2012.

Gichimu BM, Omondi CO, Gichuru EK (2010) Early agronomic performance of some new and existing Arabica coffee varieties in Kenya. Proceedings of the $23^{\text {rd }}$ International Conference on Coffee Science (ASIC). Bali Indonesia.

Gichuru EK (2005) Some notes on coffee leaf rust (Hemileia vastatrix) with regard to changing conditions of coffee production in Kenya. First International Workshop on Durable Resistance to Coffee Leaf Rust. Viçosa Brazil.

Rayner RW (1960) Rust disease of coffee. World Crops 12:222224.

Rodrigues CJ, Bettencourt AJ, Rijo L (1975) Races of pathogen and resistance to coffee rust. Annual Review of Phytopathology 13:49-70.

Silva MC, Várzea V, Guerra-Guimarães L, Azinheira HG, Fernandez D, Petitot AS, Bertrand B, Lashermes P, Nicole M. (2006) Coffee resistance to the main diseases: leaf rust and coffee berry disease. Brazilian Journal of Plant Physiology 18:119-147.

Thitai GNW, Okioga DM (1977) A new physiologic race of Hemileia vastatrix in Kenya. Kenya Coffee 42:241-243.

Van der Vossen HAM, Walyaro DJ (1981) The coffee breeding programme in Kenya: A review of progress made since 1971 and plan of action for the coming years. Kenya Coffee 46:113-130

Várzea VMP, Marques DV (2005) Population variability of Hemileia vastatrix vs. coffee durable resistance. In: Zambolim L, Zambolim E, Várzea VMP (Eds.) Durable Resistance to Coffee Leaf Rust. Viçosa Brazil. Editora UFV. pp.53-74.

Wallis JAN (1958) Coffee seed issued by the coffee research service. Coffee Board of Kenya monthly bulletin, November.

Wellman FL (1953) Americans face up to the threat of coffee rust. Foreign Agriculture 17:1-7.

TPP 575 - Received 9 April 2012 - Accepted 10 August 2012 Section Editor: Rosana Rodrigues 